\title{
Heat shock during in vitro maturation induces chromatin modifications in the bovine embryo
}

\author{
Luiz Sergio Almeida Camargo, Tiphaine Aguirre-Lavin², Pierre Adenot ${ }^{2}$, \\ Thamiris Dornelas Araujo ${ }^{3}$, Vivian Rachel Araujo Mendes ${ }^{4}$, Iuri Drumond Louro ${ }^{5}$, \\ Nathalie Beaujean ${ }^{2,6}$ and Eliza Diniz Souza ${ }^{5}$ \\ ${ }^{1}$ Embrapa Dairy Cattle, Rua Eugenio do Nascimento, Juiz de Fora, Minas Gerais, Brazil, ${ }^{2}$ UMR BDR, INRA, ENVA, \\ Université Paris Saclay, Jouy-en-Josas, France, ${ }^{3}$ Universidade Federal de Juiz de Fora, Rua José Lourenço Kelmer, s/n \\ - Campus Universitário, Juiz de Fora, Minas Gerais, Brazil, ${ }^{4}$ Universidade Federal de Viçosa, Avenida Peter Henry \\ Rolfs, s/n - Campus Universitário, Viçosa, Minas Gerais, Brazil, ${ }^{5}$ Universidade Federal do Espírito Santo/RENORBIO, \\ Vitória, Espírito Santo, Brazil and ${ }^{6}$ Univ Lyon, Université Claude Bernard Lyon 1, Inserm, INRA, Stem Cell and Brain \\ Research Institute U1208, USC1361, Bron, France
}

Correspondence should be addressed to L S A Camargo or E D Souza; Email: luiz.camargo@embrapa.br or elizadds@gmail.com

\begin{abstract}
Heat stress compromises bovine oocyte developmental competence, but the effects of high temperature during oocyte maturation on embryo chromatin organization is unknown. In this study bovine oocytes were exposed to heat shock $\left(41^{\circ} \mathrm{C}\right)$ for $12 \mathrm{~h} \mathrm{during}$ in vitro maturation and then submitted to in vitro fertilization. The heat shock did not affect $(P>0.05)$ the cleavage but reduced $(P<0.01)$ the blastocyst rate on Day 7 and Day 8 . No effect $(P>0.05)$ on total cell number was found, but the heat shock increased $(P<0.05)$ the proportion of apoptotic cells in blastocysts at Day 8. Immunofluorescence analysis of H3K9me3 and HP1 was performed in embryos at $52 \mathrm{~h}$ post in vitro fertilization. An accumulation of $\mathrm{H} 3 \mathrm{~K} 9 \mathrm{me} 3$ in the nuclei of embryos derived from heat-shocked oocytes at four-cell and eight-cell stages was found. Also, a non-expected higher proportion $(P<0.05)$ of four-cell stage embryos displaying nuclei with increased HP1 fluorescence was observed, suggesting an abnormal chromatin compaction in embryos from heat-shocked oocytes. Embryos at eight-cell stage derived from heat-shocked oocytes displayed lower $(P<0.05)$ relative amount of $H S P 40$ transcripts than control ones. In conclusion, heat shock before fertilization has an effect on embryo chromatin, influencing the accumulation of $\mathrm{H} 3 \mathrm{~K} 9 \mathrm{me} 3$ and $\mathrm{HP} 1$ in early embryos as well as further development.
\end{abstract}

Reproduction (2019) 158 313-322

\section{Introduction}

Heat stress is one of the main causes of bovine low reproductive performance in the tropics as well as in hot seasons in subtropical countries. Its effect on reproduction is supported by in vivo and in vitro studies which show that bovine oocytes are sensitive to heat stress at various stages of follicular development. It can disturb the physiology of the follicle-enclosed oocyte during the lengthy period of follicular development, leading to an oocyte with low competence for fertilization and subsequent embryo development (Roth 2015).

Exposure of cultured cumulus-oocyte complexes (COCs) to elevated temperatures $\left(41^{\circ} \mathrm{C}\right)$ during the first $12 \mathrm{~h}$ of in vitro maturation decreases the cleavage rate (Roth \& Hansen 2004, Roth \& Hansen 2005) and the proportion of oocytes that develop toward blastocyst stage (Edwards \& Hansen 1997, Roth \& Hansen 2004, Ju et al. 2005). The heat shock impairs both nuclear and cytoplasmic maturation events, such as translocation of cortical granules to the oolemma (Payton et al. 2004), cytoskeleton rearrangement (Roth \& Hansen 2005), and spindle formation (Ju et al. 2005, Roth \& Hansen 2005). Those alterations may potentially lead to incomplete nuclear maturation, fertilization failure, and/or abnormal zygote formation (Payton et al. 2004, Roth \& Hansen 2005). Moreover, heat shock-induced apoptosis has been documented for bovine oocytes exposed to elevated temperatures during maturation (Roth \& Hansen 2004).

One of the little-studied effects of heat stress on oocytes is epigenetic modification. It is clear that the epigenome can be modulated by nutritional (Murdoch et al. 2016, Longo et al. 2017) and environmental conditions (Horowitz 2016). Indeed, the epigenome provides an interface between genes and the environment and may be considered as a potential mechanism for environmental adaptation (Rissman \& Adli 2014). For instance, heat acclimation can cause transcriptional changes in genes associated to chromatin remodeling, 
heat shock proteins and apoptosis in cardiac cells of rats and those changes on chromatin structure may take part in an acclimation memory phenomenon (Tetievsky et al. 2008). Maternal heat stress increases embryo mortality in hens but supplementation of zinc in the maternal diets can reduce such effect, which was suggested to be due to increased antioxidant ability via epigenetic activation (Zhu et al. 2017). Heat shock can alter the expression of some target genes in bovine immature oocytes (Gendelman \& Roth 2012) and in vitro-fertilized embryos (Camargo et al. 2016), suggesting an epigenetic modification during oocyte growth and embryo development caused by the elevated temperature.

Epigenetic modifications related to chromatin structure include changes on DNA methylation and post-translational modifications on histones. Highly condensed chromatin (heterochromatin) is typically transcriptionally repressive, whereas non-condensed chromatin (euchromatin) is permissive to transcription (Cheung \& Lau 2005). During early development the embryo undergoes genome activation that requires epigenetic modifications such as changes on histone methylation and chromatin organization (SepulvedaRincon et al. 2016). In bovine, the major embryonic genome activation (EGA) occurs between 8- and 16-cell stages (Frei et al. 1989, Graf et al. 2014) and is associated with chromatin remodeling (Pichugin et al. 2010). Those modifications are essential to reprogram the parental genome to embryonic genome and then generate healthy embryos (Beaujean 2014). In cloned bovine embryos derived by nuclear transfer, abnormal reprogramming of heterochromatin from the somatic donor cells has been observed (Pichugin et al. 2010) and is believed to affect embryonic development (Le Bourhis et al. 2010, Pichugin et al. 2010). We postulate that one of consequences of heat shock during oocyte in vitro maturation is modifications on chromatin organization of early stages embryos. Those changes could disturb the EGA, impairing further development toward the blastocyst stage.

In order to test whether heat shock during oocyte maturation could affect chromatin remodeling in the early stage embryo, we evaluated the distribution of histone $\mathrm{H} 3$ lysine 9 trimethylation ( $\mathrm{H} 3 \mathrm{~K} 9 \mathrm{me} 3$ ) and heterochromatin protein 1 (HP1) by immunostaining of embryos at four-cell and at eight-cell stages obtained by in vitro fertilization of heat-shocked oocytes. Histone $\mathrm{H} 3$ lysine 9 (H3K9) methylation is a transgenerational epigenetic modification conserved from yeast to humans (Rissman \& Adli 2014). H3K9 methylation has been shown to correlate with transcriptional repression and serve as a specific binding site for heterochromatin protein 1 (HP1), which recognizes H3K9-methylated chromatin, oligomerizes and forms a versatile platform that participates in diverse nuclear functions, ranging from gene silencing to chromosome segregation (Eissenberg \& Elgin 2000, Lachner et al. 2001, Grewal
\& Jia 2007). During early development, there is an asymmetry on H3K9 methylation between maternal and paternal chromatin in mice (Liu et al. 2004) and cattle (Pichugin et al. 2010). In bovine in vitro-fertilized embryos, H3K9 methylation is reduced between the two- and four-cell stages and increases from the eightcell stage onward (Santos et al. 2003, Wu et al. 2011). Despite the presence of methylated $\mathrm{H} 3 \mathrm{~K} 9$, there is no clear co-localization between HP1 and H3K9me3 in bovine embryos at the two- and four-cell stages. In fact, co-localization between $\mathrm{H} 3 \mathrm{~K} 9 \mathrm{me} 3$ and HP1 is only evident at the eight-cell stage (Pichugin et al. 2010), concurrently with EGA. Changes in HP1 and/or H3K9 methylation levels could potentially disturb the EGA and impair embryonic development.

Thus, this study aimed to evaluate the effect of heat shock during oocyte in vitro maturation on development, gene expression and chromatin organization of in vitrofertilized embryo.

\section{Materials and methods}

Chemicals were purchased from the Sigma Chemical Co., unless otherwise indicated. All experimental procedures followed ethical guidelines for animal experimentation and were approved by local committee (Comissão de Etica no Uso de Animais - Embrapa Gado de Leite - CEUA EGL 02/2015 protocol).

\section{Experimental design}

Three experiments were performed in order to evaluate the developmental competence of heat-shocked oocyte after in vitro fertilization $(n=569)$, the chromatin organization of four- and eight-cell stage embryos derived from heat-shocked oocytes and the gene expression of eight-cell stage embryos derived from heat-shocked oocytes. Control groups were comprised of in vitro-fertilized embryos derived from oocytes not exposed to heat shock.

For the first experiment, immature COCs were cultured in maturation medium at $38.5^{\circ} \mathrm{C}$ for $24 \mathrm{~h}$ (control) in $5.0 \% \mathrm{CO}_{2}$ and humidified air or at $41.5^{\circ} \mathrm{C}$ for the first $12 \mathrm{~h}$ of a $24-\mathrm{h}$ culture period (heat shock) in $7.0 \% \mathrm{CO}_{2}$ and humidified air. After in vitro maturation (IVM), COCs were co-cultured with spermatozoa for $20 \mathrm{~h}$ for in vitro fertilization (IVF). Putative zygotes $(n=470)$ were denuded of cumulus cells and then cultured in CR2aa at $5 \% \mathrm{CO}_{2}, 5 \% \mathrm{O}_{2}$, and $90 \%$ $\mathrm{N}_{2}$ at $38.5^{\circ} \mathrm{C}$ in humidified air. Cleavage on Day $3(72 \mathrm{~h}$ post insemination) and blastocyst rates on Days 7 and 8 post insemination were recorded. Hatching rates were recorded on Day 8. Six replicates were performed. Total cell number and apoptosis index were determined in blastocysts at Day 8. In the second experiment the heat shock, IVM, IVF and in vitro culture (IVC) were performed as described in the first experiment. Embryos at four- and eight-cell stage at $52 \mathrm{~h}$ post fertilization $(n=58)$ were fixed in $4 \%(\mathrm{w} / \mathrm{v})$ paraformaldehyde and chromatin staining was performed with primary and secondary fluorescent antibody to detect H3K9me3 and HP1. 
Embryos from four replicates were used in this experiment. For the third experiment, IVM, IVF and IVC were also performed as described in the first experiment. Embryos at eight-cell stage at $52 \mathrm{~h}$ post fertilization were washed in PBS plus $0.1 \%$ polyvinyl alcohol and then rapidly frozen in liquid nitrogen and stored until total RNA extraction. Three pools of ten embryos per group were used.

\section{Oocytes recovery and in vitro maturation (IVM)}

Oocytes recovery and IVM were performed as previously described by Camargo et al. (2016), with a few modifications. Ovaries from predominantly Bos indicus crossbred cows were obtained at a local commercial slaughterhouse (Fripai, Juiz de Fora, MG, Brazil) and transported to the laboratory in saline solution at $34-36^{\circ} \mathrm{C}$. Follicles with $3-8 \mathrm{~mm}$ diameter were aspirated and COCs with homogeneous cytoplasm and compact layers of cumulus cells were selected for IVM and randomly allocated into control $\left(38.5^{\circ} \mathrm{C}\right)$ or heat shock $\left(41.5^{\circ} \mathrm{C}\right.$ for $\left.12 \mathrm{~h}\right)$ groups. In vitro maturation was performed for $24 \mathrm{~h}$ in tissue culture medium (TCM-199; Gibco Life Technologies, Inc.) supplemented with $10 \%$ estrus cow serum and $20 \mu \mathrm{g} / \mathrm{mL}$ follicle-stimulating hormone (FSH; Pluset, Calier, Barcelona, Spain) in $5 \% \mathrm{CO}_{2}$ and humidified air. Heat shock was performed for $12 \mathrm{~h}$ at $41.5^{\circ} \mathrm{C}$ under $7 \% \mathrm{CO}_{2}$ followed by $12 \mathrm{~h}$ at $38.5^{\circ} \mathrm{C}$ under the same conditions of control group.

\section{IVF of oocytes}

Frozen/thawed motile spermatozoa from a single Holstein bull were obtained after centrifugation at $3600 \mathrm{~g}$ for $7 \mathrm{~min}$ in Percoll (Nutricell Nutrientes Celulares, Campinas, SP, Brazil) discontinuous density gradient (45 and 90\%). The pellet was then centrifuged again at $520 \mathrm{~g}$ for $3 \mathrm{~min}$ in Fert-TALP medium. For IVF, in vitro-matured oocytes were co-cultured with $2 \times 10^{6} / \mathrm{mL}$ spermatozoa for $20 \mathrm{~h}$ in Fert-TALP in a humidified atmosphere of $5 \% \mathrm{CO}_{2}$ and $38.8^{\circ} \mathrm{C}$ in air.

\section{In vitro embryo culture (IVC)}

Presumptive zygotes were denuded in a PBS solution with $0.1 \%$ hyaluronidase and then cultured for 8 days in modified CR2aa medium supplemented with $2.5 \%$ fetal calf serum (Nutricell Nutrientes Celulares, Campinas, SP, Brazil) in incubator at $38.5^{\circ} \mathrm{C}$ under $5 \% \mathrm{CO}_{2}, 5 \% \mathrm{O}_{2}, 90 \% \mathrm{~N}_{2}$ and saturated humidity. Cleavage rate was evaluated on Day 3 post fertilization and blastocyst rate was evaluated on Day 7 and Day 8 as well as hatching rate.

\section{TUNEL labeling}

Blastocysts on Day 8 from different replicates were submitted to TUNEL staining using a commercially available kit (Dead End Fluorimetric TUNEL System; Promega) according to manufacturer's instructions. Briefly, embryos were fixed in $4 \%$ paraformaldehyde at $4{ }^{\circ} \mathrm{C}$ and then permeabilized with $0.2 \%$ Triton X-100 (Promega), both in PBS (Nutricell). Positive control embryos were previously treated with 8 units $/ \mathrm{mL}$ DNase (Promega). After permeabilization, samples were incubated in
$100 \mu \mathrm{L}$ drops with reagent mix containing enzyme solution and $90 \%$ staining solution for $1 \mathrm{~h}$ at $37^{\circ} \mathrm{C}$ in a dark humid chamber. Negative control embryos were incubated only in the staining solution without enzyme solution. After that, embryos were stained with Vectashield (Vector Laboratories Inc., Burlingame, CA, USA) plus 406-diamidino-2-phenylindole (DAPI) and mounted on slides for evaluation by fluorescence microscopy. Total cell number and apoptotic cell number per embryo were counted, and apoptotic cell index was calculated as the proportion of apoptotic cell/total cell number.

\section{Immunofluorescence, confocal microscopy and image analysis}

Immunofluorescence analysis of $\mathrm{H} 3 \mathrm{~K} 9 \mathrm{me} 3$ and $\mathrm{HP} 1$ was performed in embryos with 4- and 8-cells at $52 \mathrm{~h}$ post IVF. Embryos were fixed in $4 \%$ paraformaldehyde and permeabilized with $1 \%$ Triton X-100 in PBS. Afterward all samples were blocked with $2 \%$ BSA in PBS and then incubated with primary antibody. $\mathrm{H} 3 \mathrm{~K} 9 \mathrm{~m} 3$ labeling was performed with rabbit anti-H3K9m3 primary antibody (Millipore/Merk; 1:500 in PBS-BSA) and Cy3 anti-rabbit secondary antibody (1:200 in PBS+BSA). HP1 labeling was performed with mouse antiHP1beta primary antibody (Euromedex, 1:200 in PBS-BSA) and FITC anti-mouse secondary antibody (1:200 in PBS + BSA).

Embryos were mounted on slide in Vectashield (Vector Laboratories) under conditions of preservation of their 3D nuclear structure. They were observed with an inverted Zeiss LSM 700 confocal microscope (MIMA2 platform, INRA). The Z-stacks were acquired using a frame size of $1024 \times 1024$ with a pixel depth of eight bits and $0.370 \mu \mathrm{m}$ z-steps and with sequential multitrack scanning using the 405, 488 and $555 \mathrm{~nm}$ wavelengths of the lasers. Images were processed using an in-house pipeline analysis software, developed with Python script language and ITK library (www.itk.org).

Spatial 3D datasets were imported into the pipeline using the Bio-Formats library (http://www.loci.wisc.edu), and multichannels images were split to individual DNA, HP1 and H3K9me3 Z-stacks. Segmentation of nuclei, H3K9me3 and HP1 spots was done using three different processes. To outline correctly the nucleus, the DNA channel and the HP1 protein were combined (AddlmageFilter operation) to improve the detection of the nuclear shape, because in cattle embryos, DAPI staining alone did not allow a perfect detection of the nucleus. The binary mask of each nucleus was obtained by selecting (threshold filter) the $10 \%$ of brightest pixels in the combined image and suppressing the smallest binary areas (opening filter). Then binary structures with empty areas were filled (fill holes filter) and nuclei were discriminating from artifacts by fixing a minimal size of objects $\left(725 \mu \mathrm{m}^{3}\right)$. Finally, a color label to identify each nucleus separately was assigned. This nuclear mask was the region of interest (ROI) in the following image processing of protein channels. Since $\mathrm{H} 3 \mathrm{~K} 9 \mathrm{me} 3$ was accumulated in bright spots in the nuclei, these ones were segmented using a maximum entropy threshold filter in the ROI. The H3K9me3 were labeled individually. For the HP1 signal, accumulation of proteins resulted in spots of very different sizes and of different brightness according to the embryo developmental stages. A 2D maximum entropy 
thresholding was performed to detect spots, but a lot of punctuate structures were detected when the HP1 signal was more homogeneous. To remove unspecific spots, a mask, which detected approximately the regions enriched in HP1, was used. It was obtained by applying a Gaussian filter (sigma $=0.3 \mu \mathrm{m}$ ) on the HP1 Z-stack, and a threshold filter keeping $5 \%$ of the brightest pixels. Then, the HP1 spots were labeled individually. Measurements were done from the segmented nuclei and spots image datasets.

In addition, detailed image analysis of H3K9me3 and HP1 fluorescent staining was performed in order to identify the proportion of embryos displaying different patterns of chromatin staining (Fig. 1). Figure 1A illustrates representative merged images of immunofluorescence in four-cell and eight-cell stages embryos. Figure 1B illustrates the patterns of chromatin compaction observed (as previously established in Pichugin et al. 2010): spread (uniform staining), fibrous (small spots displaying various levels of staining) or globular (evident and big spots displaying strong staining).

\section{$R N A$ extraction, reverse transcription and relative quantification by polymerase chain reaction (RT-PCR)}

Embryos at eight-cell stage were washed in PBS and then rapidly frozen in liquid nitrogen, and stored at $-80^{\circ} \mathrm{C}$. Three pools of ten embryos per group where used for total RNA extraction with RNeasy Micro Kit (Quiagen) according to the manufacturer's instructions and treated with DNase to prevent
DNA contamination. Elution was performed with $14 \mu \mathrm{L}$ of RNAase-free water. RNA samples $(6 \mu \mathrm{L} /$ reverse transcription reaction, equivalent to 4.3 embryos) were reverse transcribed using the SuperScript III First-Strand Synthesis Supermix (Invitrogen) according to the manufacturer's instructions using oligo $(\mathrm{dT})_{20}$ primers in a final volume of $20 \mu \mathrm{L}$ (equivalent to 0.21 embryos $/ \mu \mathrm{L}$ ). Samples were first incubated at $65^{\circ} \mathrm{C}$ for $5 \mathrm{~min}$ and then for $50^{\circ} \mathrm{C}$ for $50 \mathrm{~min}$. The reaction was terminated at $85^{\circ} \mathrm{C}$ for $5 \mathrm{~min}$ and then chilled on ice. After that, $\mathrm{RNase} \mathrm{H}$ was added to the samples and incubated at $37^{\circ} \mathrm{C}$ for 20 min.

Relative quantification was performed in triplicate using real-time PCR (ABI Prism 7300 Sequence Detection Systems). Reactions were prepared using a mixture of SYBR Green PCR Master Mix (Applied Biosystems), $0.1 \mu \mathrm{M}$ primers, nuclease-free water and reverse transcribed cDNA. The volume of reverse transcribed cDNA for every primer was previously calculated, and it is shown in microliter and as embryo equivalent. For YWHAZ (tyrosine 3-monooxygenase/ tryptophan 5-monooxygenase activation protein zeta) and GAPDH (glyceraldehyde-3-phosphate dehydrogenase) were added $0.32 \mu \mathrm{L}$ of reverse-transcribed CDNA per PCR reaction (equivalent to 0.07 embryo/reaction), for ACTB (beta actin), HSP4O (heat shock $40 \mathrm{kDa}$ protein) and OCT4 (octamerbinding transcription factor 4) were added $0.64 \mu \mathrm{L} / \mathrm{PCR}$ reaction ( 0.14 embryo/reaction); for HSF1 (heat shock factor 1 ) was added $1.92 \mu \mathrm{L} / \mathrm{PCR}$ reaction (0.42 embryo/reaction) and for HSP90A1 (heat shock protein $90 \mathrm{kDa}$ class A member 1)
A
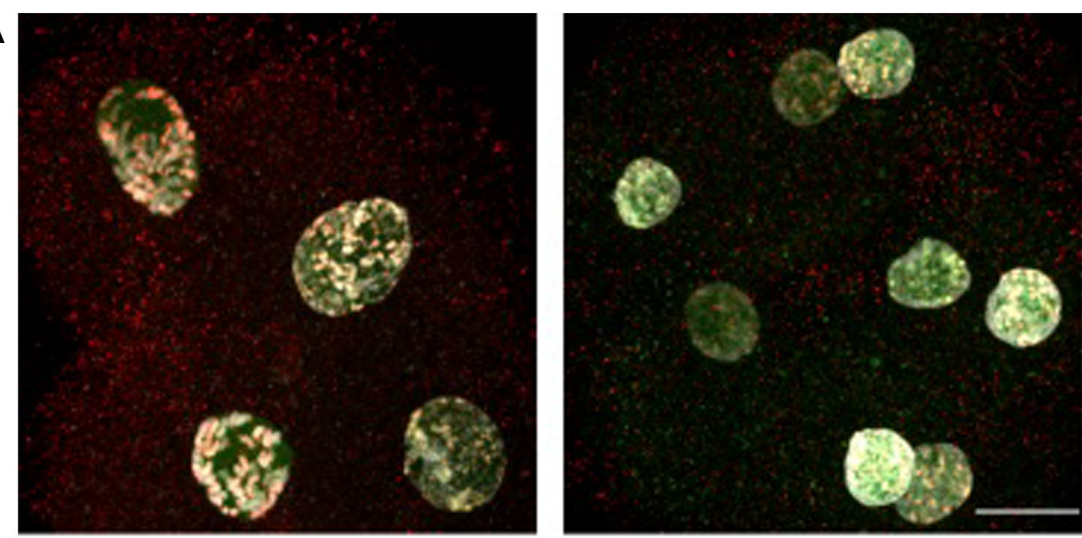

B
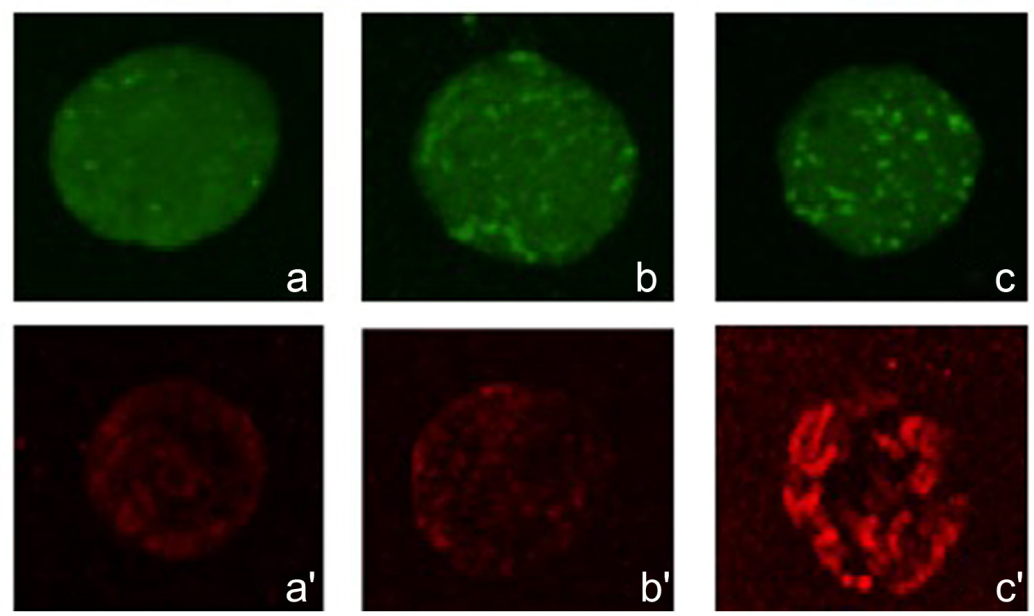

Figure 1 Representative images of the different chromatin compaction patterns established thanks to HP1 and H3K9me3 immunostaining in the nuclei of four-cell (left) and eight-cell bovine embryos (right) showing that within each embryo the distribution pattern was similar within blastomeres (A, merged images). Scale bar: $15 \mu \mathrm{m}$. Detailed images analysis with computing tools was performed on individual nuclei (B) in which three different patterns were distinguished: (a) Spread: uniform staining, (b) fibrous: small spots displaying various levels of staining, and (c) globular: evident and big spots displaying strong staining. Those analysis were performed in $3 \mathrm{D}$ on confocal z-scan that were merged on these representative examples for better visualization with HP1 in green $(\mathrm{a}, \mathrm{b}$ and $\mathrm{c})$ and $\mathrm{H} 3 \mathrm{~K} 9 \mathrm{me} 3$ in red $\left(\mathrm{a}^{\prime}, \mathrm{b}^{\prime}\right.$ and $\left.\mathrm{c}^{\prime}\right)$. 
Table 1 Primers used for real-time PCR.

\begin{tabular}{|c|c|c|c|c|c|}
\hline \multirow[b]{2}{*}{ Gene } & \multicolumn{2}{|c|}{ Primer sequence $5^{\prime}-3^{\prime}$} & \multirow[b]{2}{*}{ AT $\left({ }^{\circ} \mathrm{C}\right)$} & \multirow[b]{2}{*}{ Fragment size (bp) } & \multirow[b]{2}{*}{ Genebank access number } \\
\hline & Forward & Reverse & & & \\
\hline YWHAZ & GCAAAAGACGGAAGGTGCTG & CСTCAGCCAAGTAGCGGTAG & 59 & 197 & NM_174814.2 \\
\hline GAPDH & GGCGTGAACCACGAGAAGTAT & СССТССАСGATGССАAАGT & 53 & 119 & NM_001034034 \\
\hline$\beta$-ACTINA & GAGGСTCTСTTCСАGССТTC & GGGCAGTGATCTCTTTCTGC & 53 & 184 & NM_173979.3 \\
\hline HSF1 & АСТССААССТGGACAACСТG & TGAGTCTGGGCTGCTTTTCT & 59 & 209 & XM_010811828.3 \\
\hline HSP9OA 1 & GAGGATCCCCAGACACATGC & GACGTGTCGTCGTCTCCTTC & 62 & 143 & NM_001012670.2 \\
\hline HSP4O & AGGACTGACCAGGGACCTTT & AGACTGCATTGCСТTTGСTT & 55 & 220 & NM_001033763.1 \\
\hline OCT4 & GCTTGATCGTTTGCCСTTCT & CCCACCCTGCAGCAAATTA & 55 & 105 & NM_174580 \\
\hline
\end{tabular}

$\mathrm{AT}$, annealing temperature.

was added $0.96 \mu \mathrm{L} / \mathrm{PCR}$ reaction (0.21 embryo/reaction). $Y W H A Z, A C T B$ and GAPDH genes were used as endogenous references. The cDNA template was denatured at $95^{\circ} \mathrm{C}$ for $15 \mathrm{~min}$, followed by 45 cycles of $94^{\circ} \mathrm{C}$ for $15 \mathrm{~s}$, annealing at specific temperature for each primer for $15 \mathrm{~s}$ (Table 1 ) and extension at $60^{\circ} \mathrm{C}$ for $30 \mathrm{~s}$. Negative controls, comprising the PCR reaction mixture without nucleic acids, were also run with each group of samples. After each PCR run, a melting curve analysis was performed to confirm that a single specific product was generated. Primer efficiency was calculated using LinRegPCR software (Ramakers et al. 2003) for each reaction. The primer efficiency average was 1.92, 1.89, 1.63, 1.80, 1.86, 1.92, 1.92 to YWHAZ, GAPDH, ACTB, HSF1, HSP90, HSP4O and OCT4, respectively.

\section{Statistical analysis}

The rates of cleavage were evaluated on Day 3 and blastocysts on Days 7 and 8 after fertilization. Data of cleavage, blastocyst production and spots number and size were compared by ANOVA. Apoptosis index was analyzed by logistic regression and total cell and apoptotic cell number by linear mixed model. Proportion of embryos displaying nuclei with different staining patterns was compared by Fisher exact test. Relative transcript quantification was performed by comparative $\mathrm{Ct}$ method and the data analyzed by mixed model using the Wise Fixed Reallocation Randomization TEST in REST software (Pfaffl et al. 2002). Values are shown as mean \pm S.E.M. and the significance level was $P<0.05$.

\section{Results}

\section{Embryonic development and blastocyst total cell number and apoptosis}

The heat shock during in vitro maturation did not affect the cleavage rate, ranging from 64.5 to $74.2 \%$ between treatments. However, a significant reduction in the proportion of putative zygotes that reached the blastocyst stage was observed in the heat shock group on Day $7(P<0.01)$ and Day $8(P<0.05)$ after fertilization (Table 2). In addition, heat shock reduced $(P<0.05)$ the proportion of hatched embryos at Day 8 when compared to control, suggesting a reduction in the embryo quality (Table 2).

Blastocyst total cell number was not affected $(P>0.05)$ by the heat shock during oocyte in vitro maturation but the apoptotic cells index increased when compared to control (Table 3). Figure 2 shows representative images illustrating the total cell number and apoptotic nuclei in blastocysts from control ( $\mathrm{A}$ and $\mathrm{A}^{\prime}$ ) and heat shock ( $\mathrm{B}$ and $\mathrm{B}^{\prime}$ ) groups.

\section{Chromatin structure analysis of embryos at early stages}

For the quantitative analysis, number and size of spots (representing accumulation of $\mathrm{H} 3 \mathrm{~K} 9 \mathrm{me} 3$ or HP1) in each nucleus were counted and measured. The number of $\mathrm{H} 3 \mathrm{~K} 9 \mathrm{~m} 3$ spots in the nuclei of four-cell stage embryos was greater $(P<0.05)$ in heat shock group than in control one, whereas the spots mean size was not different. At eight-cell stage the number of spots was significantly lower $(P<0.01)$, but the mean size was higher $(P<0.02)$ in the heat shock than in the control group (Fig. 3). That increase of spots size with a decrease of spot number at eight-cell stage in the heat shock group is likely due to increase of $\mathrm{H} 3 \mathrm{~K} 9$ trimethylation that results in the fusion of several spots forming bigger but fewer spots than in the control group. The mean size of H3K9me3 spots increased between four- and eight-cell stages for both control $(385 \pm 65$ and $509 \pm 44$ voxels, respectively) and heat shock (347 \pm 32 and $692 \pm 42$ voxels, respectively) groups.

Table 2 Cleavage rate, blastocysts rate at Day 7 (BLD7) and Day 8 (BLD8) and hatched blastocysts at Day 8 (HBLD8) for bovine presumptive zygotes derived from control oocytes (control) or oocytes exposed to $12 \mathrm{~h}$ of heat shock during in vitro maturation (heat shock).

\begin{tabular}{lccccc}
\hline Treatments & $\boldsymbol{n}$ & Cleavage $(\%)$ & BLD7 $(\%)$ & BLD8 $(\%)$ & HBLD8 $(\%)$ \\
\hline Control & 240 & $74.2 \pm 4.1^{*}$ & $31.8 \pm 2.5^{*}$ & $34.1 \pm 2.9^{*}$ & $35.8 \pm 3.9^{*}$ \\
Heat shock & 230 & $64.5 \pm 5.4^{*}$ & $19.0 \pm 3.5^{+}$ & $21.2 \pm 3.8^{+}$ & $13.8 \pm 5.1^{+}$ \\
\hline
\end{tabular}

Values with different superscript symbols in the same column differ $(P<0.05)$. Values are shown as mean \pm S.E.M. $n=$ number of embryos. Data were compared by ANOVA. 
Table 3 Means of total cells number, apoptotic cells number and apoptotic index of bovine blastocysts derived from control oocytes (control) or oocytes exposed to $12 \mathrm{~h}$ of heat shock during in vitro maturation (heat shock).

\begin{tabular}{lcccc}
\hline Treatments & $\boldsymbol{n}$ & Total cells & Apoptotic cells & Apoptotic index \\
\hline Control & 20 & $113.15 \pm 6.62^{*}$ & $10.05 \pm 0.99^{*}$ & $8.75 \pm 0.69^{+}$ \\
Heat Shock & 21 & $96.29 \pm 6.59^{*}$ & $12.48 \pm 1.16^{*}$ & $12.34 \pm 0.80^{*}$
\end{tabular}

Values with different superscript symbols in the same column differ $(P<0.05)$. Values are shown as mean \pm S.E.M. $n=$ embryos number. Apoptosis index was analyzed by logistic regression and total cell and apoptotic cell number by linear mixed model.

The number and mean size of HP1 spots in the nuclei were not statistically different $(P>0.05)$ between heat shock and control group (Fig. 3). However, in both cases, the total number of HP1 spots slightly decreased suggesting that the same mechanisms of fusion occur for $\mathrm{HP} 1$ and $\mathrm{H} 3 \mathrm{~K} 9 \mathrm{me} 3$. It is also noteworthy that while HP1 spots increased in size between four-cell and eight-cell stages (from $250 \pm 39$ to $398 \pm 47$ voxels, respectively) in the control group, it decreased in the heat shock group $(404 \pm 88$ and $280 \pm 27$ voxels for four-cell and eightcell stages, respectively).

The analysis of fluorescence enabled to distinguish embryos displaying different patterns of chromatin staining between control and heat shock groups. For H3K9me3 immunofluorescence there was an increased $(P<0.01)$ proportion of embryos at four-cell stage from heat shock group displaying nuclei with globular pattern $(43.7 \%)$ when compared to control group (5.5\%), whereas no difference $(P>0.05)$ was found for the fibrous and spread patterns (Fig. 4A). At eight-cell stage, distribution of $\mathrm{H} 3 \mathrm{~K} 9 \mathrm{~m} 3$ was similar $(P>0.05)$ between control and heat shock groups for globular and fibrous
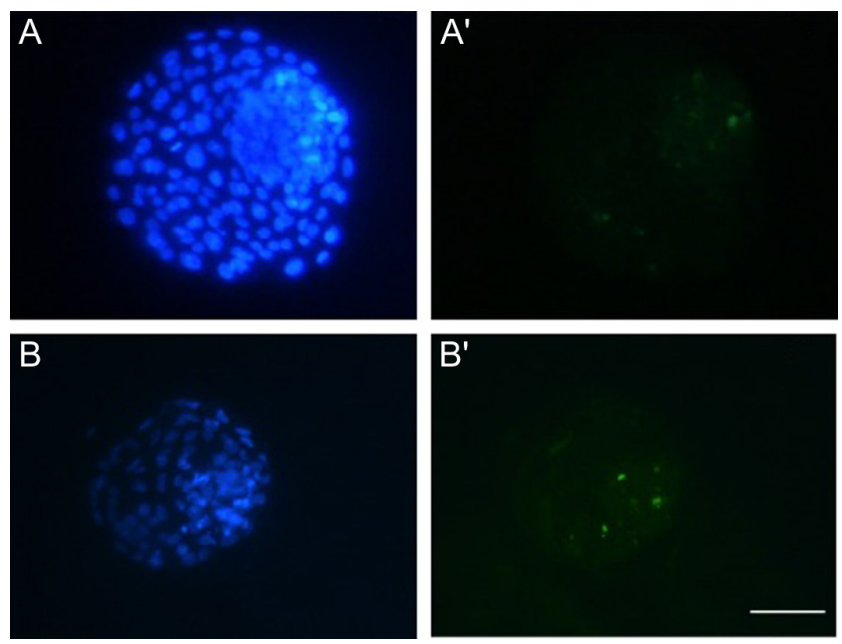

Figure 2 Representative images of DAPI and TUNEL-labeling embryos illustrating the total cell number and apoptotic nuclei (TUNEL positive) in bovine blastocysts derived from control oocytes or oocytes exposed to $12 \mathrm{~h}$ of heat shock during in vitro maturation. Scale bar: $50 \mu \mathrm{m}$. DAPI labeling: A and B, TUNEL labeling: $\mathrm{A}^{\prime}$ and $\mathrm{B}^{\prime}$. Control group: $A$ and $A^{\prime}$, heat shock group: $B$ and $B^{\prime}$.
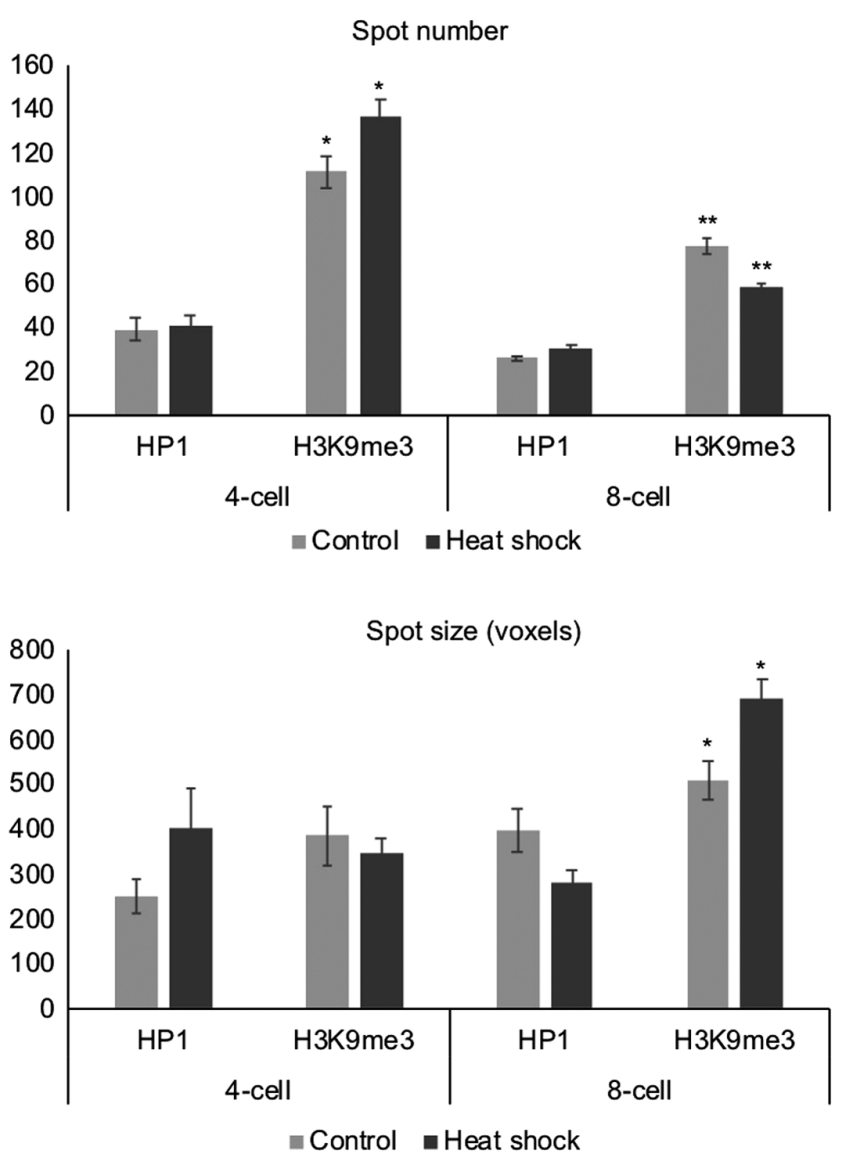

Figure 3 Analysis of trimethylation of histone3 lysine 9 ( $\mathrm{H} 3 \mathrm{~K} 9 \mathrm{~m} 3)$ and heterochromatin protein 1 (HP1) in nuclei of four-cell and eight-cell stage bovine embryos derived from control oocytes or oocytes exposed to $12 \mathrm{~h}$ of heat shock during in vitro maturation. Accumulation of $\mathrm{HP} 1$ or $\mathrm{H} 3 \mathrm{~K} 9 \mathrm{~m} 3$ is given by spot size and number per nucleus. Asterisks indicate differences between control and heat shock groups within the same patterns of staining $(* P<0.05$;

${ }^{* *} P<0.01$ ). Spots size (volume) $=$ voxels. Data of spots number and size were compared by ANOVA.

patterns (Fig. 4B) and no spread distribution was found in both groups. For HP1, the heat shock group presented higher $(P<0.05)$ proportion of four-cell stage embryos with fibrous pattern and lower $(P<0.05)$ proportion with spread pattern than the control group, and no globular pattern was found (Fig. 4C). At eight-cell stage, there was no statistical difference between the groups except that no spread pattern was found in nuclei of embryos in the heat shock group (Fig. 4D). Those results show that the heat shock during in vitro maturation increases the proportion of embryos displaying nuclei with an elevated accumulation of H3K9me3 (globular pattern) and HP1 (fibrous pattern) at the four-cell stage.

Overall, the higher number of immunofluorescence spots indicates that an increased accumulation of $\mathrm{H} 3 \mathrm{~K} 9 \mathrm{me} 3$ in the nuclei of embryos derived from heatshocked oocytes can be found at four-cell stage, one cell cycle earlier than nuclei of embryos derived from 

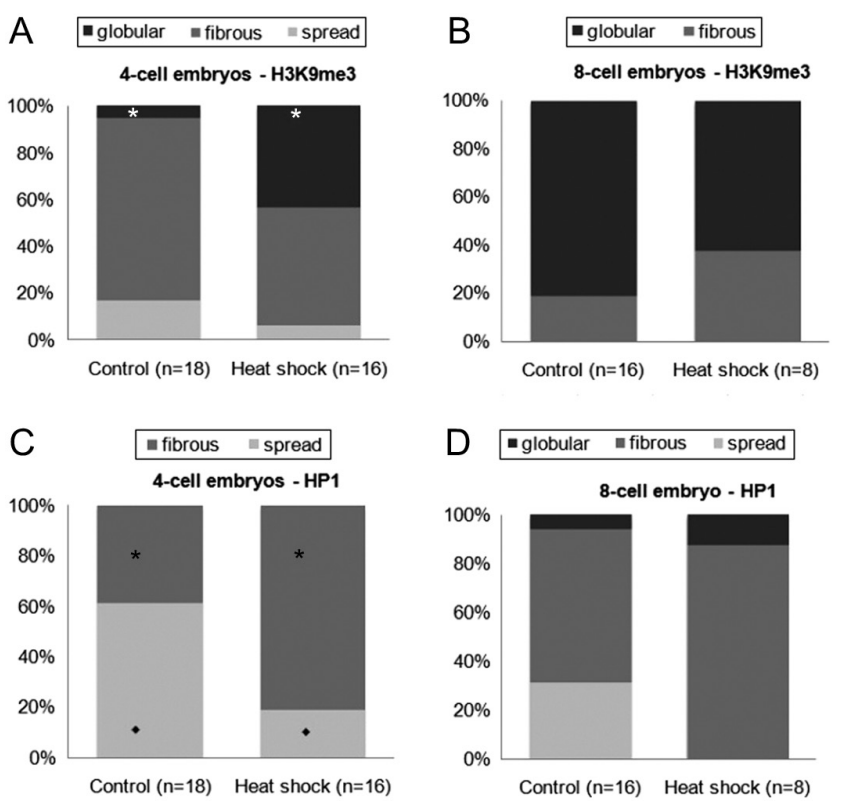

Figure 4 Percentage of four-cell and eight-cell stage bovine embryos displaying different patterns of histone 3 lysine 9 trimethylation $(\mathrm{H} 3 \mathrm{~K} 9 \mathrm{~m} 3)$ and heterochromatin protein 1 (HP1) staining in the nucleus. Spread: uniform staining, fibrous: small spots displaying various levels of staining, and globular: evident and globular spots displaying strong staining. Control: embryos derived from non-heatshocked oocytes; heat shock: embryos derived from oocytes exposed to $12 \mathrm{~h}$ of heat shock during in vitro maturation. $n=$ number of embryos. Asterisks $(*)$ indicate differences between control and heat shock groups within the same patterns of staining $(P<0.01$ for H3K9me3 and $P<0.05$ for HP1). Data of embryos displaying nuclei with different staining patterns was compared by Fisher exact test.

non-heat-shocked oocytes. This resulted in larger spots but in a small amount at eight-cell stage probably due to the union of the several spots found at four-cell stage. That precocious accumulation can also be perceived by the high proportion of four-cell embryos displaying nuclei with strong immunofluorescence staining for H3K9me3 when they are derived from heat-shocked oocytes. Similarly, the higher proportion of embryos displaying nuclei with HP1 fibrous patterns in the heat shock group at the four-cell stage correlates with the slight increase observed in the size of HP1 spots between embryos from heat shock and control groups at that stage ( $250 \pm 39$ vs $404 \pm 88$ voxels, respectively).

\section{Effect of heat shock on transcript levels in embryos}

The relative expression of four target genes (HSF1, HSP9OA1, HSP4O and OCT4) was investigated in order to associate the heat shock during in vitro maturation with gene expression in embryos at eight-cell stage. The amount of HSP4O transcripts was lower $(P<0.05)$ in embryos derived from heat-shocked oocytes, while no difference $(P>0.05)$ between groups was found for HSF1, HSP9O and OCT4 genes (Fig. 5).

\section{Discussion}

Heat stress has been a constant concern during hot seasons in both tropical and subtropical regions in cattle production systems because of its effects on reproductive and productive performance. The deleterious effect on reproduction is associated to oocytes with poor developmental competence. As previously reported (Edwards \& Hansen 1997, Hansen et al. 2001, Roth \& Hansen 2004, 2005) we found that the heat shock during in vitro maturation decreases oocyte ability to develop toward blastocyst stage after IVF and compromises embryo quality by increasing the apoptosis index. Such low developmental competence has been associated to several cytoplasmic, molecular and nuclear alterations (Payton et al. 2004, Roth \& Hansen 2005, Roth 2015); however, little is known about the effect of heat shock during oocyte in vitro maturation on chromatin remodeling post fertilization. In this study, we showed that alterations on chromatin organization can be found in early embryos derived from oocytes exposed to heat shock during in vitro maturation. The immunofluorescence analysis revealed that the nuclei of four- and eight-cell embryos had higher accumulation of $\mathrm{H} 3 \mathrm{~K} 9 \mathrm{me} 3$. Also, a higher proportion of four-cell embryos presented nuclei with strong fluorescence for H3K9me3 and HP1 when compared to embryos derived from control oocytes.

In bovine, H3K9 methylation is normally low in embryos at four-cell stage and increases from eight-cell stage onward (Santos et al. 2003, Wu et al. 2011). In our study, we found that the size of H3K9me3 spots increased from four-cell to eight-cell stage in embryos from control and heat shock groups, confirming those previous studies. Interestingly, the mean size of HP1 spots increased from four-cell to eight-cell in the control group only. As H3K9me3 is a binding site for HP1 (Lachner et al. 2001), the increase of heterochromatinization at the eight-cell stage was expected as in the control group. However, it was not observed in the heat shock group. The size of HP1 spots reduced between the fourand eight-cell stages in the heat shock group $(404 \pm 88$ vs $280 \pm 27$ voxels, respectively), despite the notable increase of H3K9me3 spots size. The large HP1 spots size as well as the proportion of embryos with the fibrous pattern nuclei suggest that heterochromatinization is stronger in four-cell stage embryos from heat-shocked oocytes when compared to control group or even to the eight-cell stage. Those findings indicate that the heat shock during oocyte maturation may hasten $\mathrm{H} 3 \mathrm{~K} 9$ trimethylation and heterochromatin formation in fourcell stage embryos.

Methylation of $\mathrm{H} 3 \mathrm{~K} 9$ associated with heterochromatization has a repressive role on gene expression (Eissenberg \& Elgin 2000, Lachner et al. 2001, Grewal \& Jia 2007), and this silencing is critical to ensure the appropriated gene activation during the 


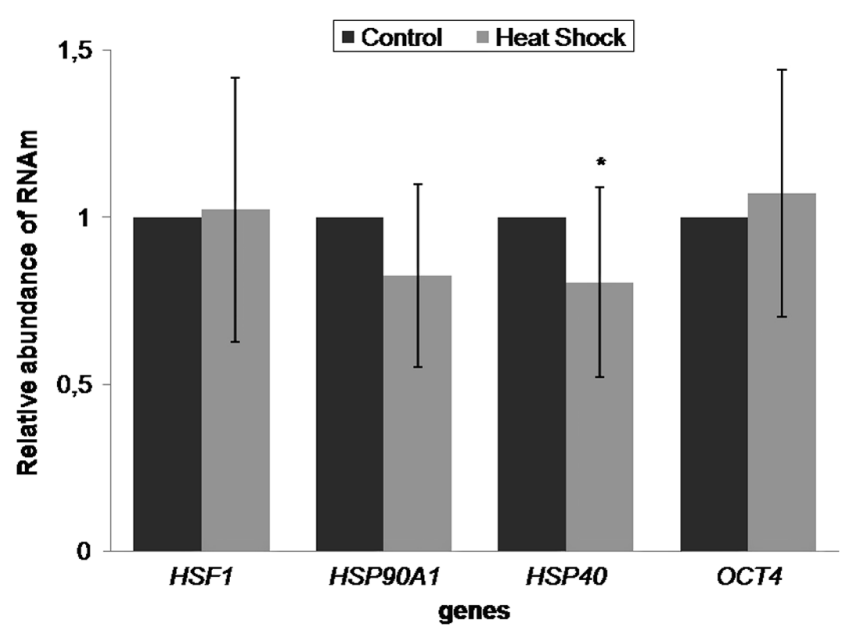

Figure 5 Relative abundance transcripts evaluation of HSF1, HSP90A1, HSP40 and OCT4 in eight-cell stage bovine embryos derived from oocytes exposed to $12 \mathrm{~h}$ of heat shock during in vitro maturation. Data of heat shock were compared to control group (calibrator). Asterisk $(*)$ indicates difference $(P>0.05)$ between control and heat shock groups. Data from three replicates. Data of relative transcript quantification was performed by comparative $\mathrm{Ct}$ method and analyzed by mixed model using the Wise Fixed Reallocation Randomization TEST in REST software (Pfaffl et al. 2002).

EGA (Nothias et al. 1995, Mason et al. 2012). Previous study showed that there is a co-localization between H3K9me3 and HP1 at eight-cell stage in bovine embryos fertilized in vitro (Pichugin et al. 2010), which coincides with major EGA. The unexpected accumulation of H3K9me3 and HP1 in the nuclei of four-cell embryos and the abnormal formation of numerous H3K9me3 condensed spots in eight-cell embryos derived from heat-shocked oocytes indicate alterations of chromatin remodeling that can perturb the EGA and, consequently, gene expression.

It was shown previously that expression of some genes, as POU5F1 and GAPDH, can be altered in eightcell embryos derived from oocytes collected in the hot season (Gendelman \& Roth 2012). In the present study we also found that the relative expression of specific gene can be altered in eight-cell embryos derived from oocytes exposed to heat shock during in vitro maturation. We analyzed the expression of genes that encode proteins associated to heat shock (HSF1, HSP90 and HSP40) and pluripotency (OCT4). Despite there was no difference on relative abundance of HSF1, HSP9O and OCT4 transcripts between treatments, the expression of HSP4O was downregulated in those embryos derived from heat-shocked oocytes, suggesting that the heat shock during oocyte maturation may perturb the expression of some genes in embryos at eight-cell stage. HSP40 is a co-chaperone with important role on cell protection under stress conditions (Gotoh et al. 2004, Lanneau et al. 2007) and alterations on its expression may impair further embryonic development under in vitro suboptimal environment. However, alterations on gene expression caused by the heat shock during in vitro maturation may be not gene specific presuming that such alterations are due to a random alteration on chromatin remodeling. This may be one of the reasons for some early stage embryos develop toward blastocyst stage, whereas others do not.

How the heat shock during IVM can affect embryo chromatin is not clear, but it may be related to disturb on redox balance. Accumulation of reactive oxygen species (ROS) is known to cause DNA damage and affects histones and DNA methylation (Mikhed et al. 2015, Niu et al. 2015). Recently, it was shown that the paternal pronucleus retains the DNA methylation when the oocyte is fertilized with spermatozoa submitted to oxidative stress (Wyck et al. 2018). As the heat shock increases the ROS production in bovine oocytes matured in vitro (Ascari et al. 2017), the alterations found in our study could be in part associated to an increased level of ROS interfering in the chromatin organization in the first cell cycles of embryos derived from heatshocked oocytes.

This is the first study showing that the heat shock during oocyte in vitro maturation can alter the chromatin organization in early in vitro-fertilized embryos. We suggest that alterations on accumulation of $\mathrm{H} 3 \mathrm{~K} 9 \mathrm{me} 3$ and HP1 caused by heat shock during in vitro maturation can negatively influence the chromatin remodeling during the EGA, affecting the expression of some genes, and contribute to impair the embryo development and quality, represented by lower blastocysts rate and higher apoptotic index.

In conclusion, the heat shock during in vitro maturation can induce alterations of H3K9me3 and HP1 accumulation in early bovine embryos, affecting embryo development and quality. Our data indicate that heat shock before fertilization can have an epigenetic effect on embryos and highlight the need of studies to understand how such alterations can influence the minor and major genome activation and how they can be modulated, in an effort to contribute to mitigate the heat stress effects on reproduction.

\section{Declaration of interest}

Nathalie Beaujean is a member of the Editorial Board of Reproduction. The other authors have nothing to disclose.

\section{Funding}

E D Souza was supported by scholarship from FAPES (Fundacao de Amparo a Pesquisa e Inovacao do Espírito Santo). This work was supported by National Council for Scientific and Technological Development (CNPq), Fapemig (APQ 543-14 
and CVZ-PPM 107-17) and the Laboratoire d'Excellence Revive Labex (Investissement d'Avenir, ANR-10-LABX-73).

\section{References}

Ascari IJ, Alves NG, Jasmin J, Lima RR, Quintão CCR, Oberlender G, Moraes EA \& Camargo LSA 2017 Addition of insulin-like growth factor I to the maturation medium of bovine oocytes subjected to heat shock: effects on the production of reactive oxygen species, mitochondrial activity and oocyte competence. Domestic Animal Endocrinology 60 50-60. (https://doi.org/10.1016/j.domaniend.2017.03.003)

Beaujean N 2014 Epigenetics, embryo quality and developmental potential. Reproduction, Fertility, and Development 27 53-62. (https:// doi.org/10.1071/RD14309)

Camargo LS, Paludo F, Pereira MM, Wohlres-Viana S, Gioso MM, Carvalho BC, Quintao CC \& Viana JH 2016 Absence of sperm factors as in the parthenogenesis does not interfere on bovine embryo sensitiveness to heat shock at pre-implantation stage. Reproduction in Domestic Animals 51 3-9. (https://doi.org/10.1111/rda.12637)

Cheung P \& Lau P 2005 Epigenetic regulation by histone methylation and histone variants. Molecular Endocrinology 19 563-573. (https://doi. org/10.1210/me.2004-0496)

Edwards JL \& Hansen PJ 1997 Differential responses of bovine oocytes and preimplantation embryos to heat shock. Molecular Reproduction and Development 46 138-145. (https://doi.org/10.1002/(SICl)10982795(199702)46:2<138::AID-MRD4>3.0.CO;2-R)

Eissenberg JC \& Elgin SC 2000 The HP1 protein family: getting a grip on chromatin. Current Opinion in Genetics and Development 10 204-210. (https://doi.org/10.1016/S0959-437X(00)00058-7)

Frei RE, Schultz GA \& Church RB 1989 Qualitative and quantitative changes in protein synthesis occur at the 8-16-cell stage of embryogenesis in the cow. Journal of Reproduction and Fertility 86 637-641. (https://doi. org/10.1530/jrf.0.0860637)

Gendelman M \& Roth Z 2012 In vivo vs. in vitro models for studying the effects of elevated temperature on the GV-stage oocyte, subsequent developmental competence and gene expression. Animal Reproduction Science 134 125-134. (https://doi.org/10.1016/j. anireprosci.2012.07.009)

Gotoh T, Terada K, Oyadomari S \& Mori M 2004 hsp70-Dnal chaperone pair prevents nitric oxide- and CHOP-induced apoptosis by inhibiting translocation of Bax to mitochondria. Cell Death and Differentiation 11 390-402. (https://doi.org/10.1038/sj.cdd.4401369)

Graf A, Krebs S, Heininen-Brown M, Zakhartchencko V, Blum H \& Wolf E 2014 Genome activation in bovine embryos: review of the literature and new insights from RNA sequencing experiments. Animal Reproduction Science 149 46-58. (https://doi.org/10.1016/j. anireprosci.2014.05.016)

Grewal SIS \& Jia S 2007 Heterochromatin revisited. Nature Reviews: Genetics 8 35-46. (https://doi.org/10.1038/nrg2008)

Hansen PJ, Drost M, Rivera RM, Paula-Lopes FF, al-Katanani YM, Krininger 3rd CE \& Chase Jr CC 2001 Adverse impact of heat stress on embryo production: causes and strategies for mitigation. Theriogenology $\mathbf{5 5} 91-$ 103. (https://doi.org/10.1016/S0093-691X(00)00448-9)

Horowitz M 2016 Epigenetics and cytoprotection with heat acclimation. Journal of Applied Physiology 120 702-710. (https://doi.org/10.1152/ japplphysiol.00552.2015)

Ju JC, Jiang S, Tseng JK, Parks JE \& Yan X 2005 Heat shock reduces developmental competence and alters spindle configuration of bovine oocytes. Theriogenology 64 1677-1689. (https://doi.org/10.1016/j. theriogenology.2005.03.025)

Lachner M, O'Carroll D, Rea S, Mechtler K \& Jenuwein T 2001 Methylation of histone $\mathrm{H} 3$ lysine 9 creates a binding site for HP1 proteins. Nature 410 116-120. (https://doi.org/10.1038/35065132)

Lanneau D, de Thonel A, Maurel S, Didelot C \& Garrido C 2007 Apoptosis versus cell differentiation: role of heat shock proteins HSP90, HSP70 and HSP27. Prion 1 53-60. (https://doi.org/10.4161/pri.1.1.4059)

Le Bourhis D, Beaujean N, Ruffini S, Vignon X \& Gall L 2010 Nuclear remodeling in bovine somatic cell nuclear transfer embryos using MG132-treated recipient oocytes. Cellular Reprogramming 12 729-738. (https://doi.org/10.1089/cell.2010.0035)
Liu H, Kim JM \& Aoki F 2004 Regulation of histone H3 lysine 9 methylation in oocytes and early pre-implantation embryos. Development 131 2269-2280. (https://doi.org/10.1242/dev.01116)

Longo R, Ferrari A, Zocchi M \& Crestani M 2017 Of mice and humans through the looking glass: 'reflections' on epigenetics of lipid metabolism. Molecular Aspects of Medicine 54 16-27. (https://doi.org/10.1016/j. mam.2017.01.005)

Mason K, Liu Z, Aguirre-Lavin T \& Beaujean N 2012 Chromatin and epigenetic modifications during early mammalian development. Animal Reproduction Science 134 45-55. (https://doi.org/10.1016/j. anireprosci.2012.08.010)

Mikhed Y, Görlach A, Knaus UG \& Daiber A 2015 Redox regulation of genome stability by effects on gene expression, epigenetic pathways and DNA damage/repair. Redox Biology 5 275-289. (https://doi. org/10.1016/j.redox.2015.05.008)

Murdoch BM, Murdoch GK, Greenwood S \& McKay S 2016 Nutritional influence on epigenetic marks and effect on livestock production. Frontiers in Genetics 7 182. (https://doi.org/10.3389/fgene.2016.00182)

Niu Y, DesMarais TL, Tong Z, Yao Y \& Costa M 2015 Oxidative stress alters global histone modification and DNA methylation. Free Radical Biology and Medicine 82 22-28. (https://doi.org/10.1016/j. freeradbiomed.2015.01.028)

Nothias JY, Majumder S, Kaneko KJ \& DePamphilis ML 1995 Regulation of gene expression at the beginning of mammalian development. Journal of Biological Chemistry 270 22077-22080. (https://doi.org/10.1074/ jbc.270.38.22077)

Payton RR, Romar R, Coy P, Saxton AM, Lawrence JL \& Edwards JL 2004 Susceptibility of bovine germinal vesicle-stage oocytes from antral follicles to direct effects of heat stress in vitro. Biology of Reproduction 71 1303-1308. (https://doi.org/10.1095/biolreprod.104.029892)

Pfaffl MW, Horgan GW \& Dempfle L 2002 Relative expression software tool (REST) for group-wise comparison and statistical analysis of relative expression results in real-time PCR. Nucleic Acids Research 30 e36. (https://doi.org/10.1093/nar/30.9.e36)

Pichugin A, Le Bourhis D, Adenot P, Lehmann G, Audouard C, Renard JP, Vignon X \& Beaujean N 2010 Dynamics of constitutive heterochromatin: two contrasted kinetics of genome restructuring in early cloned bovine embryos. Reproduction 139 129-137. (https://doi.org/10.1530/REP-080435)

Ramakers C, Ruijter JM, Deprez RH \& Moorman AF 2003 Assumptionfree analysis of quantitative real-time polymerase chain reaction (PCR) data. Neuroscience Letters 339 62-66. (https://doi.org/10.1016/s03043940(02)01423-4)

Rissman EF \& Adli M 2014 Minireview: transgenerational epigenetic inheritance: focus on endocrine disrupting compounds. Endocrinology 155 2770-2780. (https://doi.org/10.1210/en.2014-1123)

Roth Z 2015 Physiology and endocrinology symposium: cellular and molecular mechanisms of heat stress related to bovine ovarian function. Journal of Animal Science 93 2034-2044. (https://doi.org/10.2527/ jas.2014-8625)

Roth Z \& Hansen PJ 2004 Involvement of apoptosis in disruption of developmental competence of bovine oocytes by heat shock during maturation. Biology of Reproduction 71 1898-1906. (https://doi. org/10.1095/biolreprod.104.031690)

Roth Z \& Hansen PJ 2005 Disruption of nuclear maturation and rearrangement of cytoskeletal elements in bovine oocytes exposed to heat shock during maturation. Reproduction 129 235-244. (https://doi. org/10.1530/rep.1.00394)

Santos F, Zakhartchenko V, Stojkovic M, Peters A, Jenuwein T, Wolf E, Reik W \& Dean W 2003 Epigenetic marking correlates with developmental potential in cloned bovine preimplantation embryos. Current Biology 13 1116-1121. (https://doi.org/10.1016/s09609822(03)00419-6)

Sepulveda-Rincon LP, Solanas Edel Edel L, Serrano-Revuelta E, Ruddick L, Maalouf WE \& Beaujean N 2016 Early epigenetic reprogramming in fertilized, cloned, and parthenogenetic embryos. Theriogenology 86 91-98. (https://doi.org/10.1016/j.theriogenology.2016.04.022)

Tetievsky A, Cohen O, Eli-Berchoer L, Gerstenblith G, Stern MD, Wapinski I, Fiedman N \& Horowits M 2008 Physiological and molecular evidence of heat acclimation memory: a lesson from thermal responses and ischemic cross-tolerance in the heart. Physiological Genomics 34 78-87. (https://doi.org/10.1152/physiolgenomics.00215.2007) 
Wu X, Li Y, Xue L, Wang L, Yue Y, Li K, Bou S, Li GP \& Yu H 2011 Multiple histone site epigenetic modifications in nuclear transfer and in vitro fertilized bovine embryos. Zygote 19 31-45. (https://doi.org/10.1017/ S0967199410000328)

Wyck S, Herrera C, Requena CE, Bittner L, Hajkova P, Bollwein $\mathbf{H}$ \& Santoro R 2018 Oxidative stress in sperm affects the epigenetic reprogramming in early embryonic development. Epigenetics and Chromatin 11 60. (https://doi.org/10.1186/s13072-018-0224-y)

Zhu Y, Liao X, Lu L, Li W, Zhang L, Ji C, Lin X, Liu HC, Odle J \& Luo X 2017 Maternal dietary zinc supplementation enhances the epigeneticactivated antioxidant ability of chick embryos from maternal normal and high temperatures. Oncotarget 8 19814-19824. (https://doi. org/10.18632/oncotarget.15057)

Received 3 June 2019

First decision 1 July 2019

Revised manuscript received 27 July 2019

Accepted 19 August 2019 